\title{
ポリアニリンのリチウムニ次電池正極としての挙動(2) 一電解重合膜の微細構造一
}

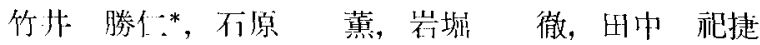

\section{Electropolymerized Polyaniline as a Positive Electrode in a Lithium Secondary Battery(2) -Fine Structure of Polymerized Films-}

Katsuhito TAKEI*, Kaoru ISHIHARA, Toru IWAHORI and Toshikatsu TANAKA

Received February 21, 1990 ; Accepted June 6, 1990

\begin{abstract}
The polyaniline films (PAn) electropolymerized in a 1 Maniline $+2 \mathrm{MHClO}$, solution were characterized by microscopic observation, porosimetry. BET adsorption mesurement and so on. The diameter of PAn fibril decreased from 2.2 to $0.4 \mu \mathrm{m}$ with increasing current density from 0.2 to $10 \mathrm{~mA} \cdot \mathrm{cm}^{2}$. The discharge capacity (especially at a high discharge rate) of a PAn film determined in a Licio, - propylene carbonate solution between 2.5 and $4.0 \mathrm{~V}$ decreased with a current density on polymerization.
\end{abstract}

1 緒 $\overrightarrow{\overline{i . n}}$ (Introduction)

導電性高分子ポリアニリン(以下PAnと略す〉はリチウ 八一次電他の正極材料上して多方面か的，基礎・応用研 究が行なれ机ている!い。

著者的も前報”で，過塩素酸水溶液中で電解重合した PAnは1アニリン単位当り約 0.5 個のC 10 、イオンを含む が，その約 50 \% は水洗处理により脱離すること，また 初期ドーナ率の高いPAnがドープ率变化幅の底い安定な 可逆的充放電特性を示すこよなど交明らかにした。

この電解重台PAnのリチ门ム…次電池正極としての厷 放電度応は、PAn固相内のアニオン移動過程が律速上報 告されているいが，PAn膜内の微細構造の演ずる役割 については明確にされていない。

そこで本研究ては。PAn膜の微細構造が電池正極特性 に及はす影響を明らかにするるために、まずフィブリル状 電解重台PAn膜?" の微細構造の重合条件に上る变化索 調心゙，さらにこの微細構浩変化が電池正極特性に与える 影響についても検討を加总た。

(財)電力中央研究斥。ルードコンディショナー特別 研究室 (宁201 㹸江甫岩可北 2-1k-1)

load Conditioner Task Team. Central Research Institute of Flectric Power Industry (11-1. Iwato kita 2 Chome. Komae Shi. Tokyo 201 ? Key Words: polyaniline, lithium secondary battery, morphology.

\subsection{PAnの電解重弇}

2 実娩方法 (Experimental)

PAnは定電流電解重合法により 10 足，1Mアニリン $+2 \mathrm{M} \mathrm{HC10}$ 水溶液中でグラファイト基板上に合成した $\left(M=\mathrm{mol} \cdot \mathrm{dm}{ }^{3}\right)$ 。電流密度を $0.2 \sim 10 \mathrm{~mA} \cdot \mathrm{cm}^{2}$ 之変化 させ，電気量は $30 \mathrm{c} \cdot \mathrm{cm}^{2}$ 上一定にした。得られたPAn 膜老 30 分間蒸留水中で浸清・摫拌し， $\mathrm{pH}>3$ に保つ ように必要に応じて蒸留水を滴加した。さらに100 ${ }^{\circ} \mathrm{Cで。}$ 24 時間以上減厓乾燥して目的の試料とした。

\section{2. 電池正極特性の評価}

グラファイト基板上のPAn膜を試料極とし，1 M LiC10 一炭酸プロピレン溶液孝電解液に，対極に Li，参照極に Li／Li 在用い、ビーカ一型セル在アルゴン霧囲気下で 組み立て。電気化学的測定に使用した。

PAn膜の正極容量は通常の装置を用い，定電流充放電 法で求めた。

\section{3. PAn膜微細構造の測定}

PAn膜の微細構造は，主にSEMにより観察し，比表面積 はBET法、鼭律一マイクロメリティックス社フローソーブ 【2300)により測定した。また，PAnフィブリル間の空隙 を細孔とみなし、細孔径の分布老水銀汪入法〈島津一マ イクロメリティックス社ポアサイザ9310)より測定した。 一方，BET法から得ら机る吸着等温線(島津一マイクロメ リティッタス社アサップ2000) に上り，0.1ｕ同以下の 
より微細な構造を調べた。また，定容積膨張法(島津 マイクロメリティックス社マルチボリウム密度計1305）

により，PAn膜の空陌部を除く真密度を测定した。

\section{3 実験結果及び検討 (Results and Discussion)}

\section{1 重合電流密度の微細構造に及ぼす影響}

各重合電流密度にお外る重合初期の電極電位老, 電気 量に対してFig.1 に示す。いず机の電流密度の場合も 通電初期に電位が立ち上がり，その徭減衰しはぼ一定電 位上なる。この挙動は，モノマーの酸化電位が最も高く。 タイマー、トリマーと重合度が高くなるにともない酸化 電位が低くなること战が原因と考えられる。

またSEM像から通電初期の $1 \mathrm{C} \cdot \mathrm{cm}^{2}$ 以下の重合電気量 の場合は，ポリマーの成長点となる核の生成が観察され た。こ机上り重合初期の電位の立ち上がりは，ポリマー の核生成反㐫に対灾するものと推定される。

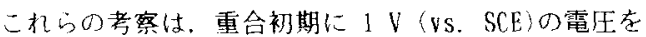
印加したのちには、アニリンモノマーが単独では酸化さ れない低い電位でも重合が進行するという報告いか方 隹裏付け的机る。

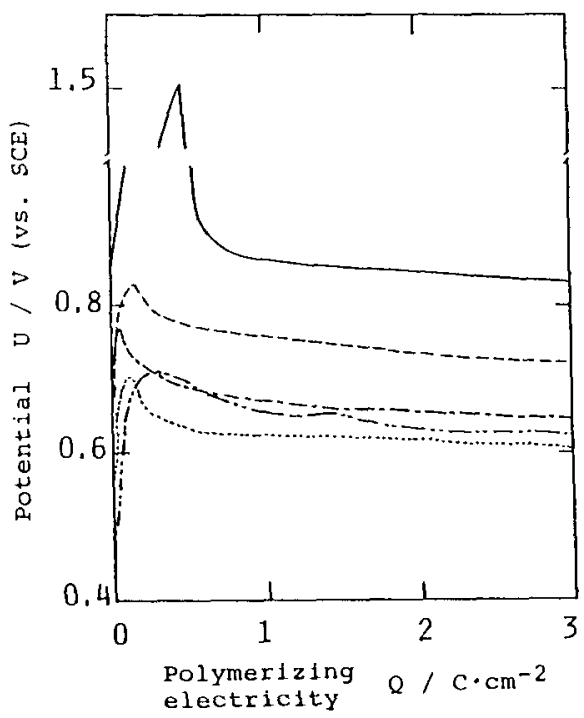

Fig. 1 Transient of electrode potential during electropolymerization at various current densities, $1 \mathrm{M}$ anline $+2 \mathrm{~N} \mathrm{HC} 10_{4}, 10^{\circ} \mathrm{C}$.

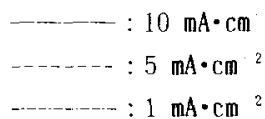

$$
\begin{aligned}
& \ldots .5 \mathrm{~mA} \cdot \mathrm{cm}^{2} \\
& \ldots \ldots=0.2 \mathrm{~mA} \cdot \mathrm{cm}^{2}
\end{aligned}
$$

一定しなった重合電位は電流密度の上昇に伴い貴な方 向に移行するが、こ扎は重合反応の過電死の増加に上る もので，ここでは同一組成の阴が合成されているおの 上考えた。

Fig. 2 に重台電気量を同一とした場合のPAn膜の乾燥 重量を重台電流密度に対して示した。ここで，電解重含 法によるPAnはアニオンを含むので，前報いし同様のア ル力り好理によってこのア二オンを完全に脱ドーナ゚し，

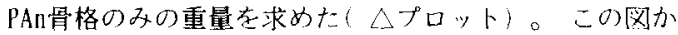
ら，電流密度の変化にかかわらず。ほぼ同一量のPAnが 合成され，初期ドープ率も $40 \sim 45 \%$ \%範囲内にある こ上がかかった。

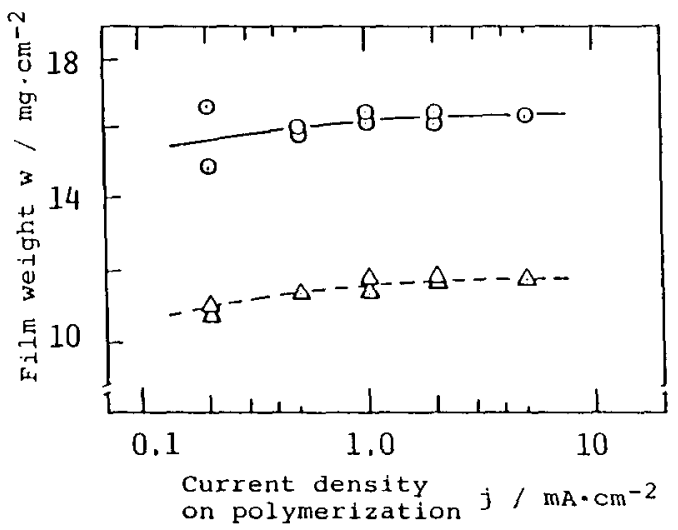

Fig. 2 Changes in PAn film weight with current density on electropolymerization $\left(30 \mathrm{C} \cdot \mathrm{cm}{ }^{2}\right)$.

$O$ : rinsed with water for $1 \mathrm{~h}$

$\triangle$ : succeeding $\mathrm{NaOH}$ treatment

低電流密度でPAn合成量のやや少ないのは，同一重台 電気量で比較しているため，重合時間が長かったこと $\left(0.2 \mathrm{~mA} \cdot \mathrm{cm}{ }^{2}\right.$ で $\left.41.7 \mathrm{~h}\right)$ ，また後述する上うに膜が 厚くもろいため水洗時に多少剝離したことが, 原因とし て考えられる。

合成されたPAn膜の表面状態を Fig. 3 に示す。いずれ の電流密度の場合もフィブリル状で,フィブリルの径は 高電流密度ほよ゙小さくなっったここの傾问は結晶成長時の 冷却速度の影響亡類似しており，高成長速度に対応する 高電流密度はよ゙細いフィブリルが得られる。さらに詳細 に観察すると，各フィブリルの表面は径の大きいものほ よ゙粗くなることがわかった。

また， $2 \mathrm{~mA} \cdot \mathrm{cm}^{2}$ の一定電流密度で，重合電気量を变 化させた場合のPAn膜の断面を Fig. 4 に示す。重合電気 量を $10 \mathrm{C} \cdot \mathrm{cm}$ ”以上にする上，膜内で厚さ方向の不均一 性が生ずることがわかった。 
このため，表面・表面近傍・中央・内部（電極基板近 倍) 04 つに分けて $30 \mathrm{C} \cdot \mathrm{cm}^{2}$ 重合電気量のPAn膜のフィ ブリル径をSEM像上り測定し、それれぞれの平均值上重合 電流密度との関係老Fig.5 に示したが，特に低電流密

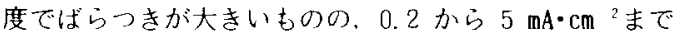
の電流密度の上昇に伴いフィブリル径は約 1/5に隇少す ることがかかった。

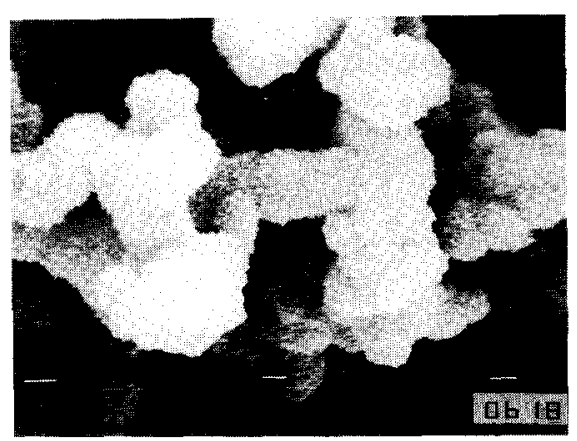

$0.2 \mathrm{~mA} \cdot \mathrm{cm}^{-2}$

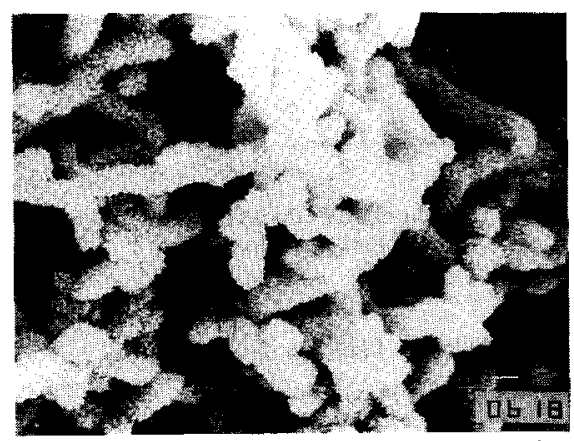

$1.0 \mathrm{~mA} \cdot \mathrm{cm}^{-2}$

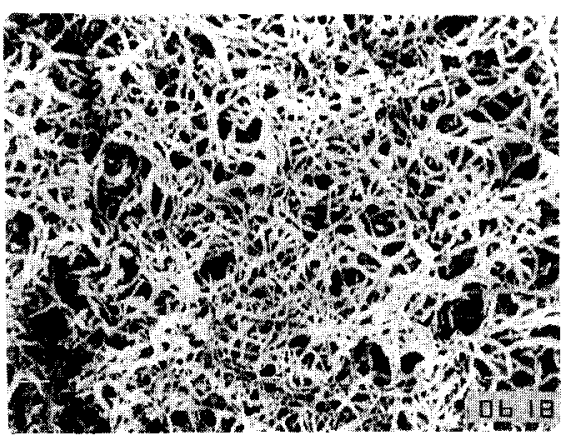

$10 \mathrm{~mA} \cdot \mathrm{cm}^{-2}$

$5 \mu \mathrm{m}$

Fig. 3 Surface SEM photos of PAn films obtained at various current densities.

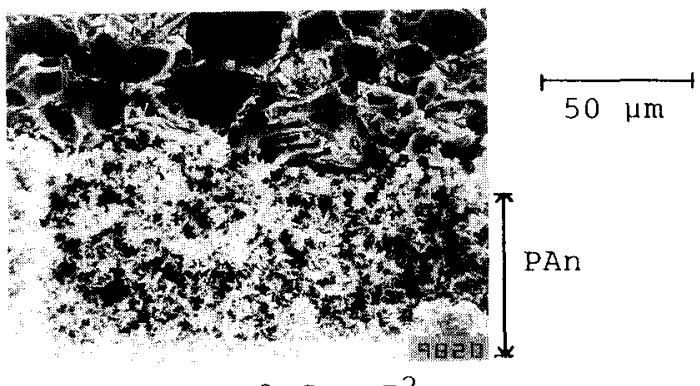

$3 \mathrm{C} \cdot \mathrm{cm}^{-2}$

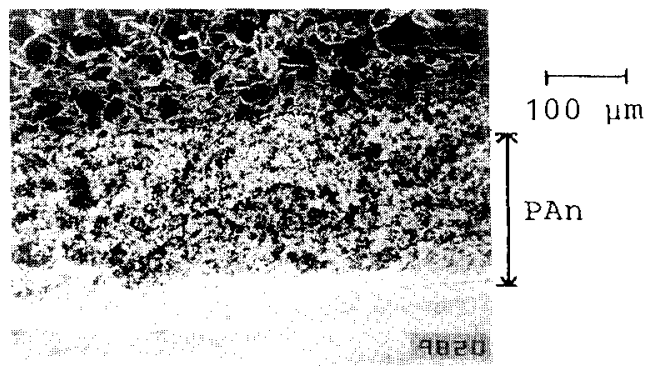

$10 \mathrm{C} \cdot \mathrm{cm}^{-2}$

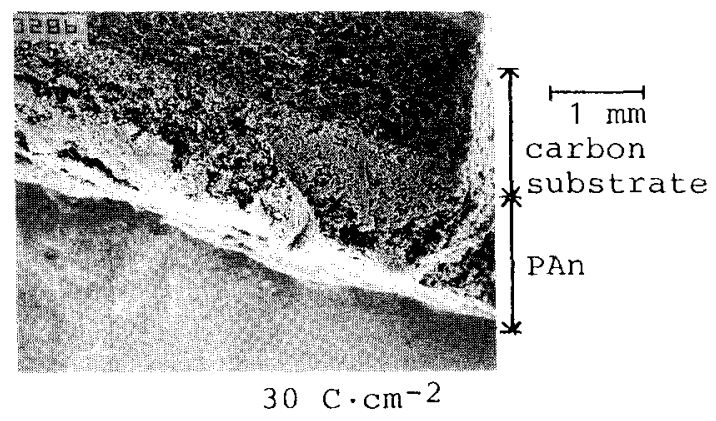

Fig. 4 Cross-sectional SEM views of PAn films, obtained at $2 \mathrm{~mA} \cdot \mathrm{cm}^{2}$.

\section{2 PAn物性値の変化}

PAnのリチウム二次電池正極ししての充放電反応は, それぞれ電解液からのア二オンのドープ・脱ドープで, このアニオンがPAn固相内を移動(搪散)する過程が律速 である上考えられている゚・。 3.1 の結果上り，高重 合電流密度で得られる細いフィブリルほよ゙アニオンの移 動距離も短くなるため，優れた正極特性を示すことが予 想されるが，PAn/電池電解液界面の立体構造よフィブリ ル径上の相関関係は明確ではない。

このため，微細構造の変化に伴うPAn表面状態の変化 を知る目的で、種々の测定を行なった。

Fig. 6 にマクロ的観点からPAnの膜厚上真密度を測定 した結果を，さらにPAn/電池電解液界面の定量化の指標 となるBET比表面積を，重合電流密度に対して示す。 


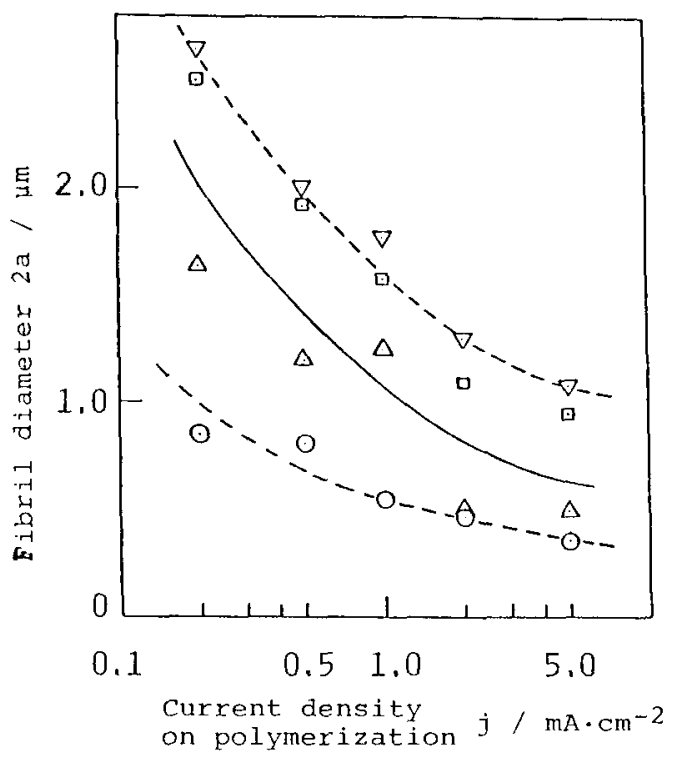

Fig. 5 Changes in a fibril diameter of PAn with current density on electropolymerization.

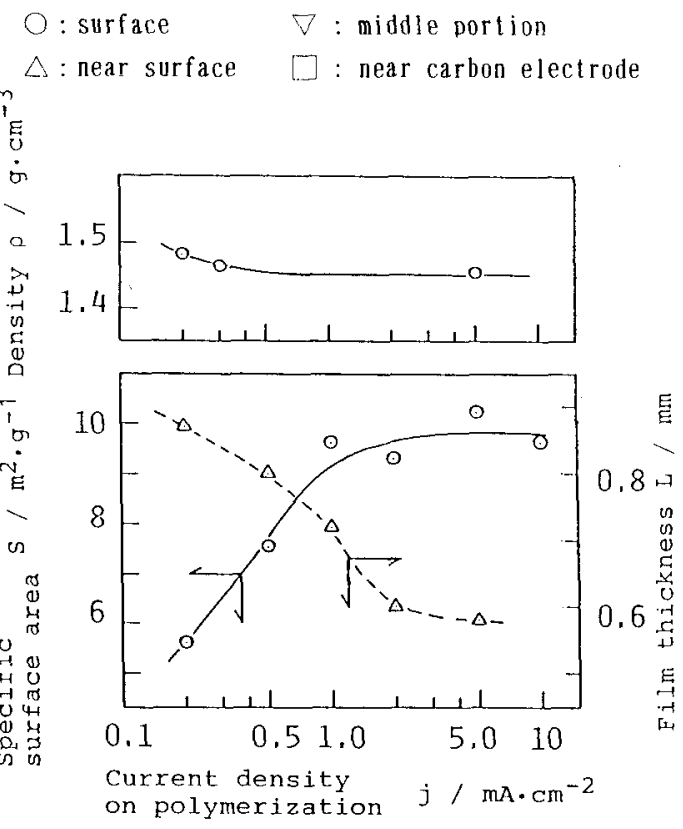

Fig. 6 Changes in density, specific surface area and film thickness with current density on electropolymerization.

重合電流密度の上昇に伴いPAn膜厚は减少するが，真

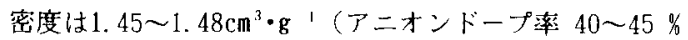
の初期状態) でほぼ一定であるので，膜の空隙部が咸少
し緻密さが增大していることがわかった。

一方，比表面積は重合電流密度と上もに增加し， $1 \mathrm{~mA} \cdot \mathrm{cm}^{2}$ 以上では約 $10 \mathrm{~m}^{2} \cdot \mathrm{g}$ 1で飽和傾向を示した。

これらのフィブリルを里純な円柱モデルで近似し，次 式に示すフィプリル表面の粗度 SRF S Surface roughness factor) 在求めた。

S、（BET法より求如比表面皘）

SRF

Sッ（円杜モデル仮定の表面積）

$S_{M} \fallingdotseq 2 \pi \mathrm{a} l \quad \rho=W / \pi \mathrm{a} 21$

であるのだ

$\mathrm{S}_{\mathrm{u}} \fallingdotseq 2 \mathrm{~W} / \mathrm{a} \rho$

で与えられる。ここで，aはSEM像より計測したフィブル ル半径,ははPAnフィブリルの長さ、Wは質量, ○はPAn の真密度である。

Fig. 7 にSRFの重合電流密度依存性走示す。高重合電 流密度で得られる細いPAnフィブリルては、平滑な円柱 側面を仮定したモデルに比へ，約2.8倍の粗さをもつこ よがわからた。またSEM像観察結果と一致して，SRFは重 合電流密度の低下(フィブリル径の增加)に伴って増加 し. $0.2 \mathrm{~mA} \cdot \mathrm{cm}{ }^{2}$ では約 9 であった。これらの結果は。 フィブリルが細くなることによって膜の表面皘が増加す る傾向が、ーィブリル自体の表面が平滑になることによ り約1/3に緩和されたこととして説明される。

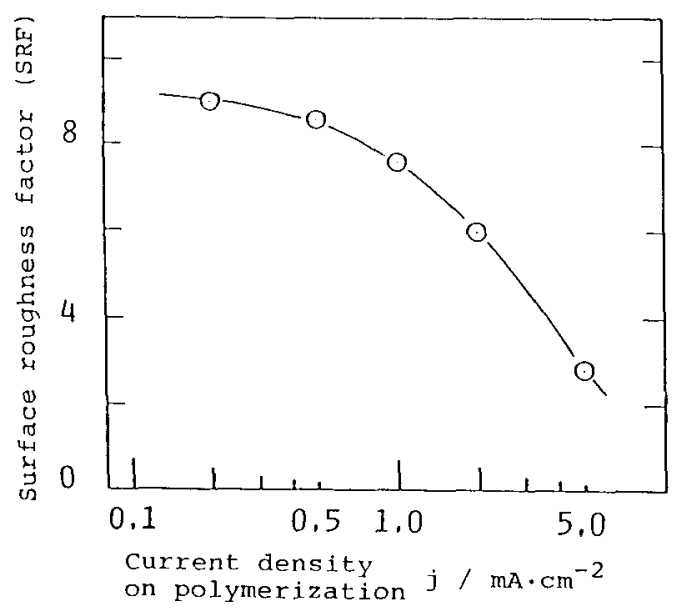

Fig. 7 Change in surface roughness factor with current density on electropolymerization. 


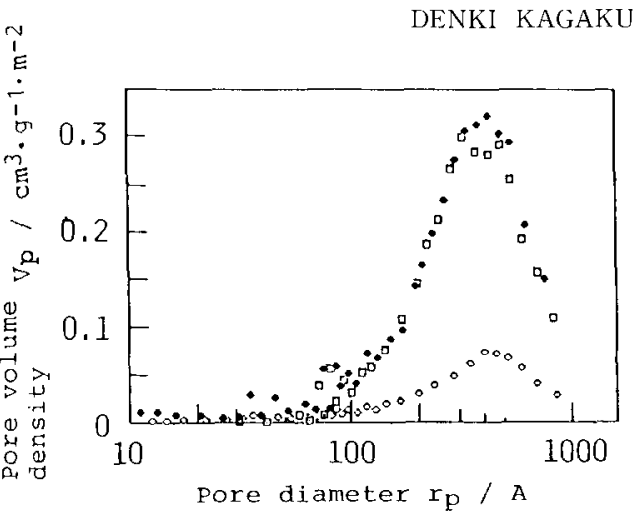

さらにBET法より求めた比表面積は， $\mathrm{N}_{2}$ 分子(約 $16 \AA$ ) の吸脱着より測定するため，電解液よの接触面積よりも 大きな值と考えられる。

このため，フィブリル間の空隙を細孔上見なし，この 細孔径の抒布を水銀压入法により $0.01 \sim 100 \mu \mathrm{m}$ の籍 囲で測定した。その結果をFig. 8 に示すが，低重合電 流密度のフィブリル径の大きいPAnほよ゙， 細孔径分布の 極大値は大きくなり，より太いフィブリルから作られる 空隙ほよ゙大きいことがわかった。しかし $0.3 \mu \mathrm{m}$ 以下 では全細孔体積はほ亡んど变化せず，水銀圧入法では フィブリル表面の粗さは細孔として測定できなかった。

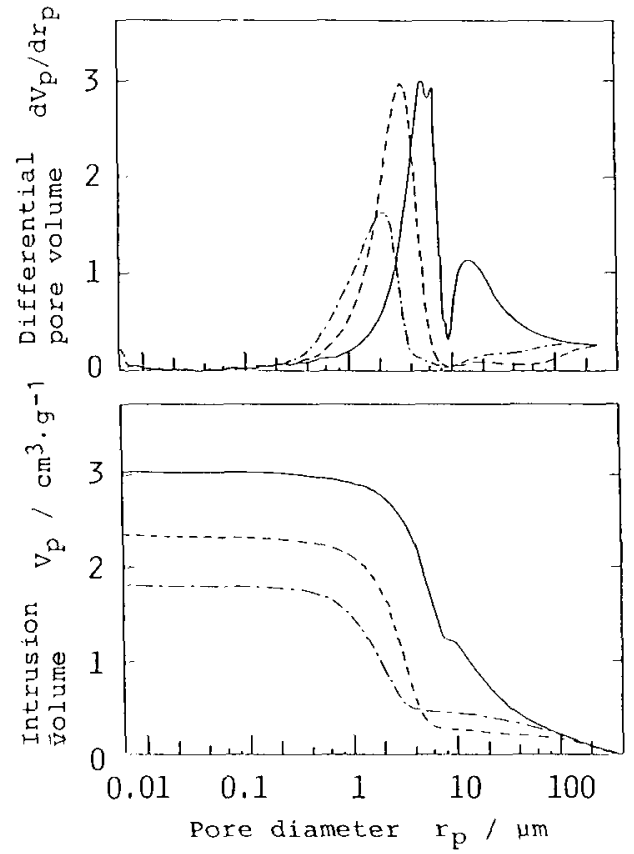

Fig. 8 Pore volume distribution curves of PAn films obtained at various current densities.

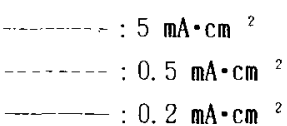

そこでBET法から得られる吸着等温線より $0.1 \mu \mathrm{m}$ 以 下の細孔を求めた。平滑円柱モデルの单位表面皘当りの 細孔の分布をFig.9に示す。図より重合電流密度に依 存せず，300～500 ^に極大值がある同様の分布となり フィプリル表面の粗さを示すものと推定された。この範 囲の全細孔体積は重合電流密度の增加に伴い20２5 $\mathrm{mm}^{3} \cdot \mathrm{g}$ 'と增加するが，単位面積当りでは図に示すよう に低重合電流密度のPAnが大きく、より粗い表面である ことが褒付けられた。
Fig. 9 Fine pore volume density distribution of PAn obtained at various current densities.
$0: 5 \mathrm{~mA} \cdot \mathrm{cm}$
$\square: 0.5 \mathrm{~mA} \cdot \mathrm{cm}^{2}$
: $0.2 \mathrm{~mA} \cdot \mathrm{cm}^{2}$

以上上り，重合電流密度の堌加によもなってPAnのフ ィブリル径は減少し，PAn/電池電解液界面の実効表面積 も大きくなるが，細いフィブリルの表面ほよ゙平滑になる ため，この傎向がやや緩和されることがわかった。

\section{3 正極特性に及ぼす影響}

PAnの安定な酸化・還元反応による $2.5 \mathrm{~V} \sim 4.0 \mathrm{~V}$ の 電位域で，充電電流密度を $0.2 \mathrm{~mA} \cdot \mathrm{cm}^{2}$, 放電電流密度 を $0.1 \sim 0.5 \mathrm{~mA} \cdot \mathrm{cm}^{2}$ として定電流充放電を行ない, その容量を求めた。

今回用いたPAnは，重合電気量 $30 \mathrm{C} \cdot \mathrm{cm}^{-2}$ アニリン骨 格重量 $11.5 \mathrm{mg} \cdot \mathrm{cm}^{2}$ であり，充放電に伴いアニリン単 位当り 0.5 個 のアニオンの出入りが可能と仮定すると $1.69 \mathrm{mAh} \cdot \mathrm{cm}^{2}$ となる。

したがって、 $0.1 \mathrm{~mA} \cdot \mathrm{cm}^{2}$ は約 17 時間率, $0.5 \mathrm{~mA}$ - $\mathrm{cm}^{2}$ では約 3.4 時間率の放電速度に相当する。各放電 電流密度でのサイクル試験を行なった結果，その放電容 量を脱ドープ率（ドープ率：C104／－HN-O)-モル比） の变化幅 $-\Delta X 亡 し て F i g .10$ に示す。

前報”で述べたように，電解重合PAnの合成後の洗浄 時間がサイタル初期特性に影制を及ぼすため，脱ドープ 率としては， $0.5 \mathrm{~h}$ の洗浄時間で安定した容量の得られ る10 サイクル目の値を採用した。

高重合電流密度のPAnは放電速度を上げた場台も容量 低下率が低く，出力特性においても優机ていることがわ かった。一方，低重合電流密度のPAnは正極容量が放電 速度に依存し，高出力時には容量が著しく低下する傾向 が認められた。

なおここれらの電気化学的特性については，今後詳し く検討する予定である。 


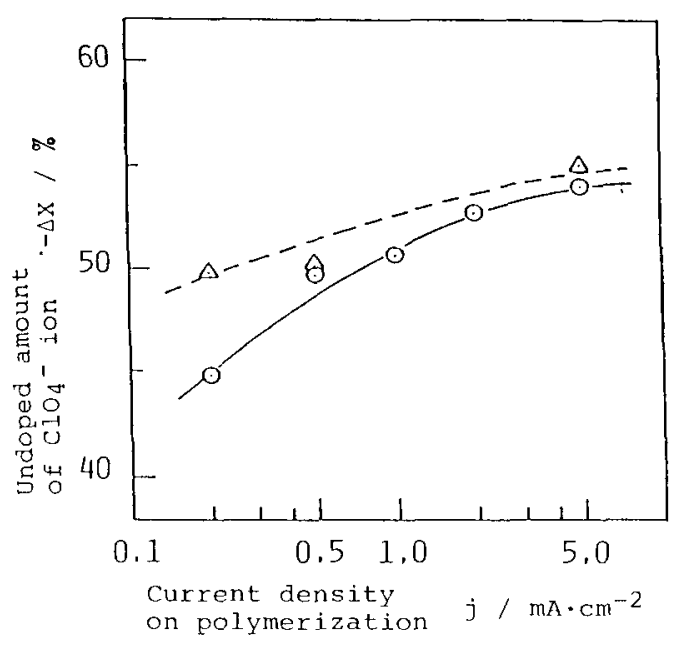

Fig. 10 Changes in undoped amount of $\mathrm{ClO}_{4}$ ion on discharge with current density on electropolymerization $(30 \mathrm{C} \cdot \mathrm{cm}$ ")

$$
\begin{aligned}
\text { Charge : } & 0.2 \mathrm{~mA} \cdot \mathrm{cm}^{2} \\
\text { Discharge : } & 0.1 \mathrm{~mA} \cdot \mathrm{cm}^{2}(\Delta) \\
& 0.5 \mathrm{~mA} \cdot \mathrm{cm}^{2}(O)
\end{aligned}
$$

\section{4 結 論 (Conclusion)}

過塩素酸溶液中で定電流法により電解重台したPAn膜 は，重台電流密度を高くするとフィブリルが細くなるが 真密度は变化せず，膜が緻密になることによって電池正 極乞しての実効表面樍が增加した。この結果, 高重台電 流密度で合成したPAn膜は，特に高出力時の正極特性に 優れていることがわかっだ。

本研究を取りまとめるにあたり，有益な御教示を頂い た慶応義塾大学理工学部応用化学科 美浦隆助教授 に深 く感謝致します。

\section{文献}

1) E.M. Genius. A. A. Syed and C. Tsintavis, Mol. Cryst. Liq. Cryst., 121, $186(1985)$.

2）木谷晧, 賀谷雅詔, 広本恭之, 佐々木和夫, 電気化学, 53,592（1985).

3) K. Okabayashi, F. Goto, K. Abe and T. Yoshida, Syn. Met. , 18, 365 (1987).

4) 竹井勝仁, 石原㸔, 岩堀徹, 田中祀捷, 電気化学, 57,563 (1989)

5) D. D. Perlmutter and B. Scrosati, Solid State I0nics, 27, 115 (1988).

6) 竹原善一郎, 金村聖志, 米沢晋, 第29回電池討論会, 3B11.

7) S. Taguchi and T. Tanaka. 3rd IMLB Extended Abstracts, ST-21 (1986).

8) W. Huang, B. D. Hunphrey and A. G. MacDiarmid, J. Chem. Soc. Faraday Trans. 1, 82, 2385 (1986).

9) T. Jinsong. W. Lixiang, Z. Fongfang and M. Zhishen, Mol. Cryst. Liq. Cryst., 160, 175 (1988).

10) A. Diaz. J.Crowley, J.Bargon. G. Gardini and J. Torrance, J. Electroana I. Chem., 215, 401 (1986).

1) K. Sasaki. M. Kaya, J. Yana and A.Kitani, J.Electroanal. Chem., 215,401 (1986). 